\title{
Fabrication of a polymerase chain reaction micro-reactor using infrared heating
}

\author{
Ki-Sik Im ${ }^{\dagger}$, Duk-Soo Eun, Seong-Ho Kong, Jang-Kyoo Shin, and Jong-Hyun Lee
}

\begin{abstract}
A silicon-based micro-reactor to amplify small amount of deoxyribonucleic acid (DNA) has been fabricated using microelectro-mechanical systems (MEMS) technology. Polymerase chain reaction (PCR) of DNA requires a precise and rapid temperature control. A Pt sensor is integrated directly in the chamber for real-time temperature measurement and an infrared lamp is used as external heating source for non-contact and rapid heating. In addition to the real-time temperature sensing, PCR needs a rapid thermocycling for effective PCR. For a fast thermal response, the thermal mass of the reactor chamber is minimized by removal of bulk silicon volume around the reactor using double-side $\mathrm{KOH}$ etching. The transparent optical property of silicon in the infrared wavelength range provides an efficient absorption of thermal energy into the reacting sample without being absorbed by silicon reactor chamber. It is confirmed that the fabricated microreactor could be heated up in less than $30 \mathrm{sec}$ to the denaturation temperature by the external infrared lamp and cooled down in $30 \mathrm{sec}$ to the annealing temperature by passive cooling.
\end{abstract}

Key Words : polymerase chain reaction, PCR, micro-reactor, MEMS, IR heating

\section{Introduction}

Since Northrup et al. have realized a PCR chip using MEMS technology in $1993^{[1]}$, a great deal of efforts has been dedicated to the development of miniaturized PCR chips by a number of laboratories. In general, microPCR chips have been classified into the continuousflow type $\mathrm{e}^{[2]}$ and micromchamber type $\mathrm{e}^{[1.3]}$. A continuousflow type has well-defined three individual temperature zones, kept constant at different temperatures over time, and has a long channel delivering DNA sample. On the other hand, a micro-chamber type has one reactor filled with the DNA sampleand heat source that controls the temperature. The latter has more advantages, such as simple structure and small size that give suitability for portable devices with low cost. In addition, the microchamber type allows more flexibility in the temperature cycling for DNA amplification.

A wide variety of materials, such as silicon, glass, poly-dimethylsiloxane (PDMS), polyimide and so on, has been used to realize PCR chips. Most of the poly-

School of Electronic \& Electrical Engineering, Kyungpook National University 1370, Sangyuk-dong, buk-gu, Daegu, 702-701

'Corresponding author: peter 4 (O)magion.com

(Received: April 11, 2005, Accepted : June 3, 2005) mer materials, such as PDMS and polyimide, are frequently considered desirable due to the easiness in manipulation, the biocompatibility and transparent property ${ }^{\mid 4.5]}$. However, silicon is preferable material than others for realizing an intelligent PCR chips with integrated circuit as a part of a lab-on-a-chip (LOC) or system-on-a-chip (SOC), which we are finally aiming at. Furthermore, well-developed processing technologies with silicon give more chances to realize micro-scaled devices that have complex structures. For these reasons, silicon is chosen for the bottom wafer where the PCR micro-chamber is fabricated. The transparent top glass opens a channel to the direct observation of the sample injected into the PCR chamber. In this paper, a MEMSbased silicon micro-reactor for DNA amplification and its IR-mediated thermal cycling are demonstrated.

\section{Fabrication}

The schematic view of the PCR micro-reactor is illustrated in Fig. 1. The starting material is $490 \mu \mathrm{m}$-thick and double-side polished (100) silicon wafer, coated on both sides with a low-stress LPCVD silicon nitride layer. The nitride layers on both sides are patterned using photolithography and following reactive ion etch- 


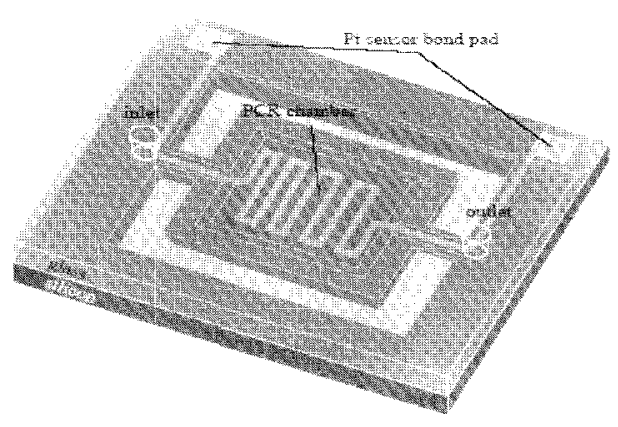

Fig. 1. Structural design of the PCR micro-reactor.

ing (RIE). Using the patterned nitride layers as the mask, anisotropic wet etching through the silicon wafer is performed in aqueous potassium hydroxide $(\mathrm{KOH}, 30$ $w t \%, 90^{\circ} \mathrm{C}$ ). In order to define the reaction chamber the silicon is etched from the top side to a depth of $190 \mu \mathrm{m}$ in advance and then the bulk-silicon parts underneath and around the chamber are etched away from the back side to minimize the thermal capacity of the reaction chamber ${ }^{[3,6]}$. This results in a suspended PCR chamber by two silicon bridges that contain the inlet and outlet channels, as shown in Fig. 2. The well size is $3 \times 3 \times 0.19$ $\mathrm{mm}^{3}$ so that the total volume of the well is $1.71 \mu l$.

A successful patterning of the Pt temperature sensor in $190 \mu$ m-deep reactor chamber is achieved by applying additional process steps to improve the uniformity of photoresist coating at the sharp convex corners. The sharp corners are rounded off using two-step $\mathrm{KOH}$ etching, followed by maskless tetramethyl ammonium hydroxide (TMAH, $\left.\left(\mathrm{CH}_{3}\right)_{4} \mathrm{NOH}\right)$ etching step. Fig. 3 shows the SEM photos of rounded corner and Pt temperature sensor fabricated in the PCR well.

For PCR-compatible surface coating, a silicon dioxide $(350 \mathrm{~nm})$ was deposited by plasma enhanced chemical vapor deposition (PECVD) on the silicon wafer. The most used materials for the realization of biomedical coatings are based on carbon, in the form of amor-

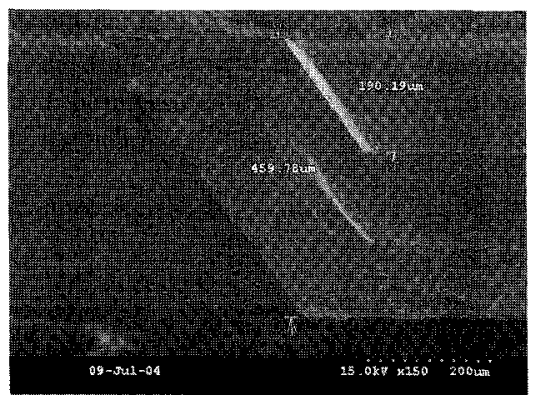

(a)

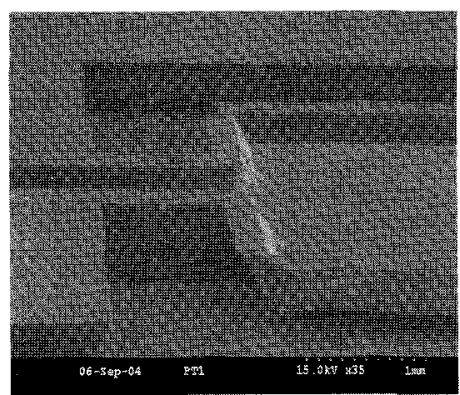

(b)

Fig. 2. Suspended PCR micro-reactor by in/outlet channels for minimizing the thermal mass; (a) Cross section of PCR micro-reactor and (b) SEM photo of suspended PCR micro-reactor.

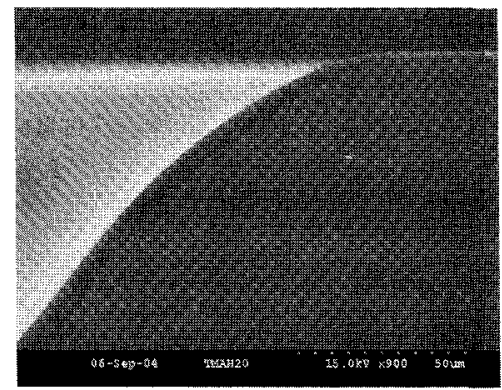

(a)

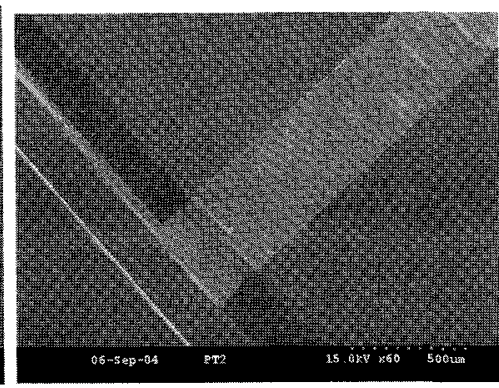

(b)

Fig. 3. Rounded convex corner and Pt temperature sensor fabricated through the non-planar in/outlet channels; (a) Cross section of the convex corner rounded in TMAH, coated with AZ9260 photoresist and (b) Pt patterning through the rounded concave corner. 
phous carbon $(\mathrm{a}-\mathrm{C})$, hydrogenated amorphous carbon $(\mathrm{a}-\mathrm{C}: \mathrm{H})$ and diamond like carbon (DLC). Also silicon carbide $(\mathrm{SiC})$, both in its amorphous and microcrystalline form, shows good possibilities for its use in the biomedical field, especially thanks to its properties of great hardness and resistance to degradation. Another material of great interest is silicon oxide in its amorphous form (a-SiO), which shows characteristics of hardness and mechanical resistance similar to the ones of glass. There are very few scientific information on the biocompatibility of a-SiO $\mathrm{S}_{2}$ thin films, but some studies exist, that deal with the use of bioactive glasses, which include $\mathrm{SiO}_{2}$ in their components ${ }^{[7.8]}$. Also of interest are the amorphous alloys based on silicon and nitrogen (a-SiN), which show characteristics that are quite similar to a-SiO.

Soda-lime glass wafer, which has inlet and outlet holes prepared by sand blasting, is finally bonded with the completed bottom silicon wafer using dry film photoresist Ordyl BF 410 (manufactured by Tokyo Ohika Kogyo co., Ltd. $)^{[9-11]}$. The bonded PCR chip is shown in Fig. 4.

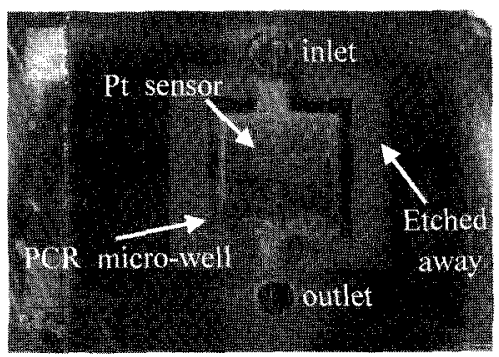

Fig. 4. The fabricated PCR micro-reactor.

\section{Finite Element Analysis (FEA) of the PCR micro-reactor}

Finite element analysis (FEA) is used for investigating the steady-state temperature distribution of the proposed PCR micro-reactor with fully-reduced mass, minimized heat capacity around the reactor chamber. Because of symmetry considerations, it is sufficient to model only a quart of the proposed device for a simplicity. As the boundary conditions of simulation, the temperatures at the bottom plane and two side-planes of the proposed device are fixed to the ambient tempera-
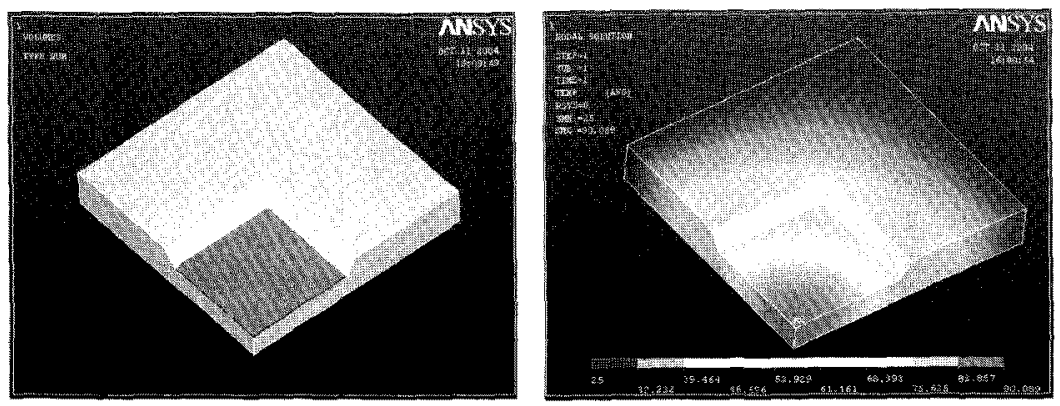

(a) PCR micro-reactor with full mass.
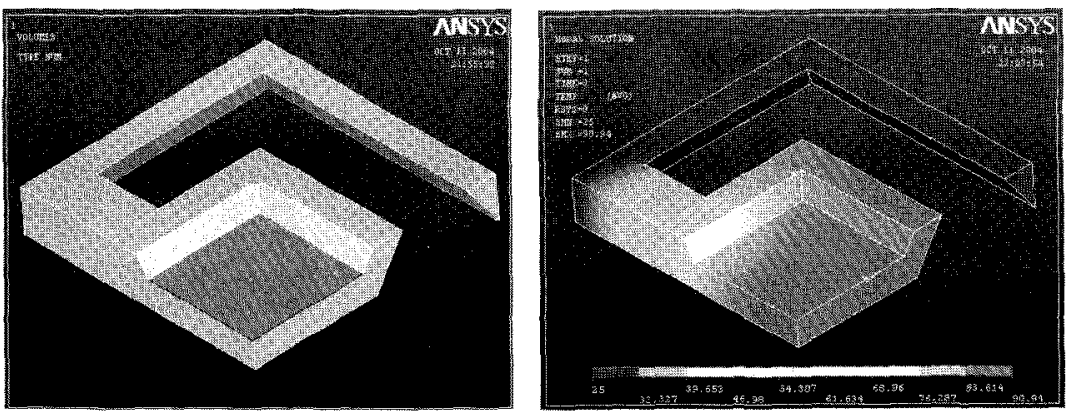

(b) PCR micromreactor with fully-reduced mass.

Fig. 5. Thermal analysis of the proposed structures. 
ture. Fig. 5 shows the simulated temperature distributions on (a) the reactor with full mass and (b) the reactor with fully-reduced thermal mass around the reactor chamber, when the heat generation is imposed upon the bottom plane of the reactor chamber until it reaches at $90^{\circ} \mathrm{C}$. A uniform temperature distribution is observed in the reactor chamber with fully-reduced thermal mass.

\section{Measurements}

The measured resistance of the fabricated Pt sensor was about 200 250 $\Omega$ The linear property of the sensor can be represented as follows

$$
R=R_{0}\left[1+\alpha\left(T-T_{0}\right)\right],
$$

where $R$ is the resistance of the sensor at temperature $T\left({ }^{\circ} \mathrm{C}\right), R_{0}$ is the resistance at reference temperature $T_{0}$ and $\alpha$ is the temperature coefficient of resistance (TCR) of the Pt sensor. The resistance change of the fabricated Pt sensor was measured over the temperature range 20 $\sim 100{ }^{\circ} \mathrm{C}$ in a temperature/humidity-controlled chamber and shown in Fig. 6, the measured TCR was about

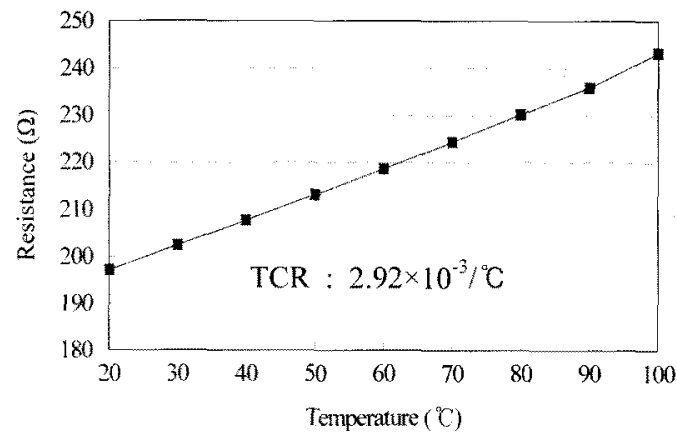

Fig. 6. Measured resistance of Pt sensor as a function of temperature.
$2.92 \times 10^{-3}{ }^{\circ} \mathrm{C}$ that is close to that of bulk Pt $\left(3.92 \times 10^{-3} /\right.$ $\left.{ }^{\circ} \mathrm{C}\right)^{[12]}$

The measurement setup to measure the heating performance of the fabricated device is illustrated in Fig. 7. The actual heating performance has been demonstrated with de-ionized water of $1.7 \mu l$ filled in the micro-reactor instead of real DNA sample. A $100 \mathrm{~W}$ tungsten lamp illuminates the sample filled in the fabricated whole micro-reactor chamber and $\mathrm{Pt}$ sensor formed in the micro-reactor chamber detects the realtime temperature of the sample by observing the change in its resistance ${ }^{[13]}$. The measured heating and passive cooling profiles are shown in Fig. 8. As soon as the lamp illuminates the PCR micro-reactor, the temperature rapidly increases. As can be seen in Fig. 8, it takes less than $30 \mathrm{sec}$ to reach to the denaturation temperature $\left(90 \sim 96^{\circ} \mathrm{C}\right.$ ) from the room temperature and requires another $30 \mathrm{sec}$ to reach into the annealing tempearture $\left(50-65^{\circ} \mathrm{C}\right)$ in PCR process. These results demonstrate that the fabricated PCR reactor is applicable to the PCR process.

\section{Conclusions}

A MEMS-based PCR micro-reactor for amplifying DNA has been fabricated and characterized. A new technology, rounding sharp convex comers, has been devised to overcome the difficulty to form a Pt sensor in the reactor chamber along the non-planar inlet/outlet channel.

Differently from conventional $\mathrm{PCR}$ chips that have micro-heater and temperature sensor on the back side of the reactor chamber with a distance through bulk silicon, the device reported in this paper has a Pt temperature sensor integrated directly in the reactor chamber

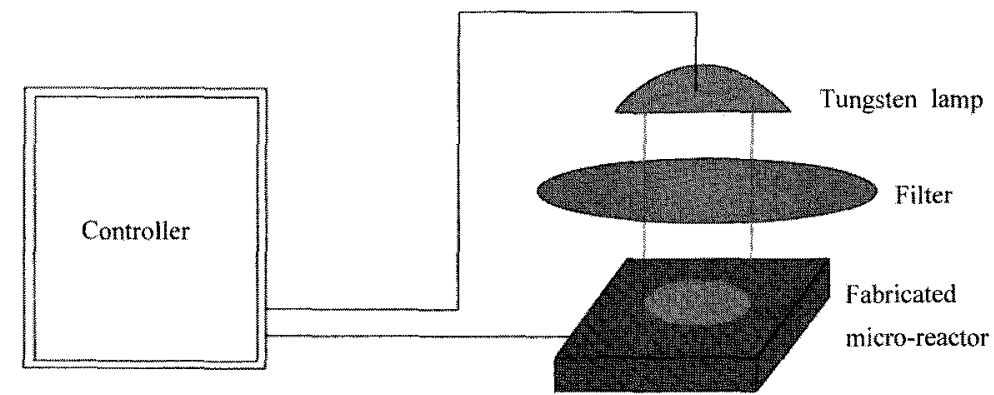

Fig. 7. Experimental Set-up. 


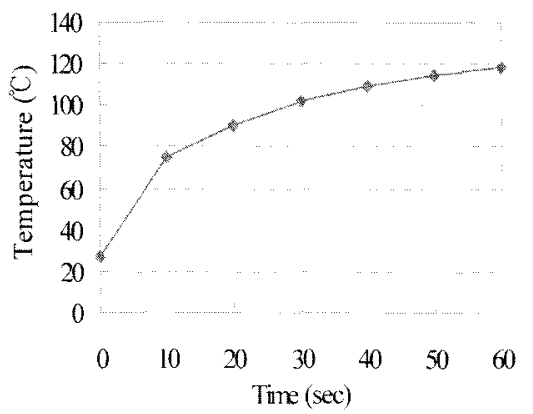

(a)

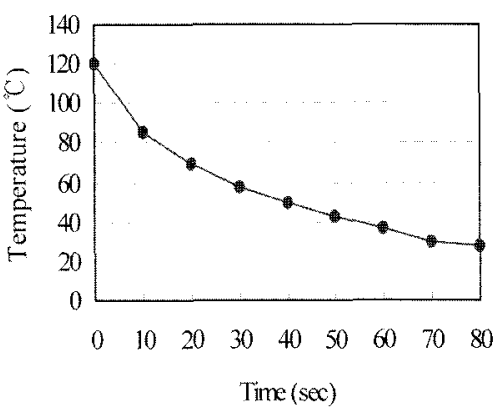

(b)

Fig. 8. Heating and cooling profile.

for improved real-time temperature measurement and uses non-contact infrared-mediated heating for more effective PCR amplification. In fact, the heating method using IR source results in more efficient and uniform heat transfer to the sample because the silicon microreactor does not absorb most part of IR wavelength range ${ }^{[14]}$, while only the sample does due to the fact that a specific IR-active absorption band for the sample is limited.

\section{Acknowledgement}

This research was supported in part by Kyungpook National University Research Fund, 2004.

\section{References}

[1] M. A. Northrup, M. T. Ching, R. M. White, and R. T. Watson, "DNA amplication with a microfabricated reaction chamber", Proc. Int. Conf. SolidState Sensors and Actuators, pp. 924-926, 1993.

[2] M. U. Kopp, A. J. de Mello, and A. Manz, "Chemical amplification: Continuous-flow PCR on a chip, Science", Science, vol. 280, pp. 1046-1048, 1998.

[3] J. H. Daniel, S. Iqbal, R. B. Millington, D. F. Moore, C. R. Lowe, D. L. Leslie, M. A. Lee, and M. J. Pearce, "Silicon microchambers for DNA amplification", Sensors and Actuators A, vol. 71, pp. 8188, 1998.

[4] A. Fuchs, H. Jeanson, P. Claustre, J. A. Gruss, F. R.Cavalier, P. Caillat, U. Mastromatteo, M. Scurati, F. Villa, G. Barlocchi, P. Corona, and B. Grieco, "A silicon lab-on-chip for integrated sample preparation by PCR and DNA analysis by hybridization", Int. Conf. on Microtechnologies in Medicine \&
Biology, pp. 227-231, 2002.

[5] Y.-K. Kim, "The Trend of MEMS Technology", J. Sensors Soc., vol. 8, no. 5, pp. 354-358, 1999.

[6] D. S. Yoon, Y. S. Lee, H. J. Cho, S. W. Sung, K. W. Oh, J. H. Cha, and G. B. Lim, "Precise temperature control and rapid thermal cycling in a micromachined DNA polymerase chain reaction chip", $J$. Micromechanics and Microengineering, vol. 12, pp. 813-823, 2002.

[7] S. L.-Esteban, E. Saiz, S. Fujino, T. Oku, K. Suganuma, and A. P. Tomsia, "Bioactive glass coatings for orthopedic metallic implants", $J$. of the Europ. Ceramic Soc., vol. 23, pp. 2921-2930, 2003.

[8] J. Ballarre, J. C. Orellano, C. Bordenave, P. Galliano, and S. Cere, "In vivo and in vitro evaluation of vitreous coatings on cobalt base alloys for prosthetic devices", J. of Non-Cryst. Solids, vol. 304, pp. 278-285, 2002.

[9] C. denBesten, R. E. G. van Hal, J. Munoz, and P. Bergveld, "Polymer bonding of micro-machined silicon structures, micro electro mechanical systems", IEEE MEMS, vol. 92, pp. 104-107, 1992.

[10] J. E.-Ali, I. R. P.-Nielsen, C. R. Poulsen, D. D. Bang, P. Telleman, and A. Wolff, "Simulation and experimental validation of a SU-8 based PCR thermocycler chip with integrated heaters and temperature sensor", Sensors and Actuators A, vol. 110, pp. 3-10, 2004.

[11] E. Kukharenka, M. M. Farooqui, L. Grigore, M. Kraft, and N. Hollinshead, "Electroplating moulds using dry film thick negative photoresist", $J$. Micromechanics and Microengineering, vol. 13, pp. S69S74, 2003.

[12] K.-D. Song, Y.-I. Bang, S.-M. Lee, Y.-S. Lee, N.-J. Choi, B.-S. Joo, M.-G. Seo, J.-S. Huh, and D.-D. Lee, "Characteristics and fabrication of micro gas sensor with single electrode", J. Sensors Soc., vol. 
11, no. 6, pp. 350-357, 2002.

[13] A. F. R. Huhmer and J. P. Landers, "Noncontact infrared-mediated thermocycling for effective polymerase chain reaction amplification of DNA in nanoliter volumes", Anal. Chem., vol. 72, pp. 5507-5512,
2000 .

[14] D. K. Schroder, R. NoelThomas, and J. C. Schwartz, "Free carrier absorption in silicon", IEEE J. Solid State Circuits, vol. SC-13, pp. 180-187, 1978.

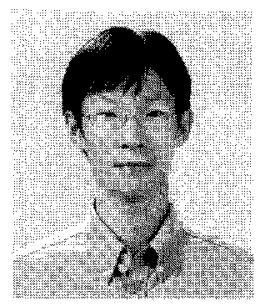

\section{임 기 식}

-2002년 2월 경북대학교 무기재료공학과 졸업(공하사)

- 2005년 2월 경북대학교 전자공학과 졸업 (공학석사)

- 주관심분야 : Bio-MEMS

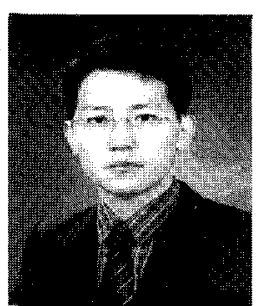

\section{공 성 호}

- 1993년 경북대학교 전자공학과 졸업 (공학사)

- 1996년 일본 동북대학교 정밀기계공학 졸업(공학석사)

- 2002년 네덜란드 델프르트 공대, 전자공 학과 졸업(공학박사)

- 현재 경북대학교 전자전기컴퓨터학부 교수

- 주관심분야 : Bio-MEMS, MOEMS

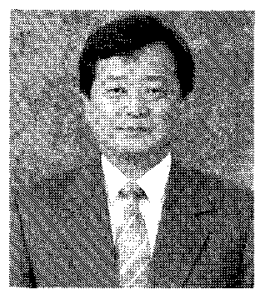

\section{이 좋 현}

- 1972년 2월 경북대학교 전자공학과 졸업 (공하사)

-1976년 2월 경북대학교 전자공학과 졸업 (공학석사)

- 1981년 프랑스 그레노블 공대 반도체공 학과 졸업(공학박사)

- 현재 전자전기컴퓨터학부 고수

- 주관심분야 : Bio-MEMS, SOI

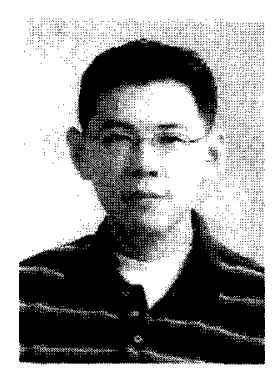

\section{은 덕 수}

-2001년 2월 계명대학교 물리학과 졸업 (이학사)

-2003년 2월 경북대학교 센서 밎 디스풀 레이공학과 졸업(공학석사)

-2003년 3월 현재 경북대학교 전자공 학과 박사과정

- 주관심분야 : Bio-MEMS, RF-MEMS, 열전변환기, 마이크로머시넝

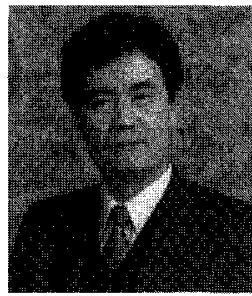

\section{신 장 규}

- 1978년 2월 서울대학교 전자공학과 졸업 (공학사)

- 1980년 2월 KAIST 전자공학과 졸업 (공학석사)

-1991년 5월 미국 콜로라도 주립대학교 전자공학과 졸업(공학박사)

- 현재 경북대학교 전자전기컴퓨터학부 교수

- 주관심분야 : 이미지 및 바이오 센서 